\title{
EL LEGADO DE WILHELM CRÖNERT
}

A description of the lexicographical manuscripts of Wilhelm Crönert kept at Göttingen.

\section{INTRODUCCIÓN}

Wilhelm Crönert fue catedrático de la Universidad de Estrasburgo, donde realizó una obra muy importante como editor, lexicógrafo y estudioso en general de las letras griegas. Su reedición y elaboración total y renovada del diccionario griego-alemán de Passow marca un hito en la lexicografia, no ya griega, sino general '. Lástima que por diversas circunstancias los fascículos editados por Crönert con el nombre de Passow's Wörterbuch der griechischen Sprache völlig neu bearbeitet (Gotinga, Vandenhoeck und Ruprecht, comenzados en 1912) no pudieran seguir siendo editados, abarcando solamente hasta ’̀े $\dot{x}$.

Tras la guerra del 14, y consiguiente incorporación de Alsacia a Francia, Crönert pierde la cátedra. Entonces se retira a un pueblo de la Selva Negra, donde se aísla con una ingente biblioteca, además de importantes colecciones artísticas y numismáticas, buscando la autarquía intelectual y económica: es decir, intenta rodearse de todos los libros necesarios para seguir sus investigaciones, a la vez que se hace todos sus muebles y estanterías, zapatos, etc. Allí se dedica a leer textos griegos y recoger material lexicográfico de toda clase de autores a lo largo de varios años (en el manuscrito estudiado, muchas veces la recogida de material está fechada hasta 1943, año en que muere a causa de un accidente en su propia casa. A su muerte donó su biblioteca y un manuscrito con materiales lexicográficos a la Akademie der Wissenschaften de Gotinga con el expreso deseo de que se siguiera publicando el diccionario griego que él había comenzado.

\footnotetext{
'Sobre el carácter e importancia de esta obra cf. J. López Facal, «Historia de la lexicografia griega moderna», en F. R. Adrados, E. Gangutia, J. López Facal y C. Serrano Aybar. Introducción a la lexicografia griega, Madrid 1977, pp. 116-119.
} 


\section{LOS MATERIALES LEXICOGRÁFICOS INÉdTOS DE CRÖNERT}

\section{El manuscrito de Crönert}

Durante los meses de julio y agosto de 1977 fui a Gotinga con una beca de Intercambio entre el C. S. I. C. y la Deutsche Forschungsgemeinschaft, para estudiar los manuscritos lexicográficos inéditos legados por Crönert a la Academia de Ciencias de la citada ciudad alemana, y que se guardan en depósito en el Seminar für Klasische Philologie de su Universidad. Alli, gracias a las extraordinarias facilidades proporcionadas por el director del Seminario, Dr. Classen, por el Dr. Schindel y el resto del personal de dicha institución, pude estudiar los materiales lexicográficos objeto de mi viaje.

El manuscrito lexicográfico legado por Crönert consiste en 24 tomos en folio formados por hojas dobles. Cada dos de ellos tienen pegada una columna del Diccionario de Passow, con añadidos marginales muy densos a plumilla y lápiz de la mano de Wilhelm Crönert. Este semimanuscrito (que en adelante llamaremos con la abreviatura Man. Crö.) abarca desde la alfa a la épsilon, comprendiendo también la parte editada de $\boldsymbol{\alpha}$ a $\dot{x} \boldsymbol{v} \dot{x}$.

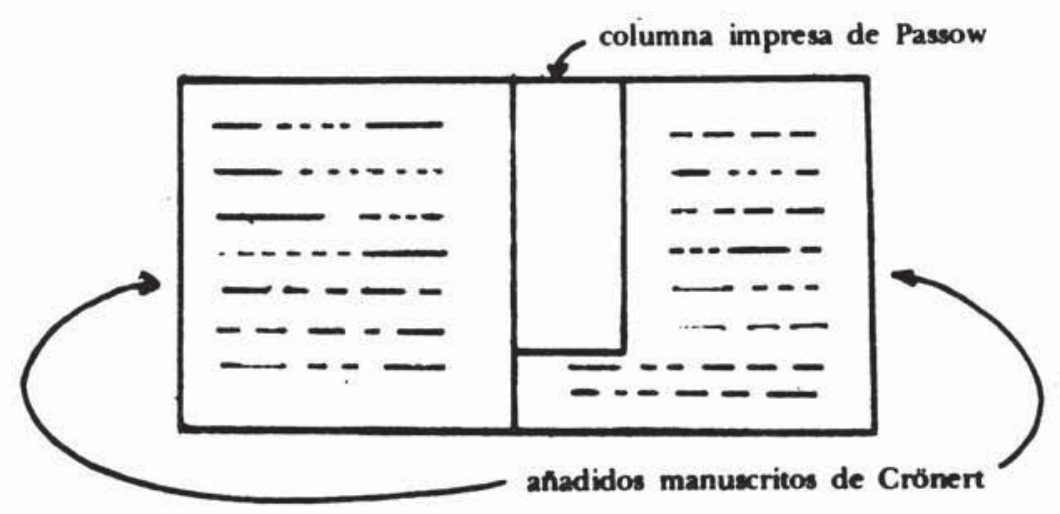

En una primera lectura pude observar que la tarea inicial de Crönert fue interpretar, corregir y documentar mejor las citas de Passow. Es posible que para esta tarea consultara los libros del propio Passow, varios de los cuales aparecen ahora en la biblioteca de Crönert.

Pero la documentación que Crönert añade sobrepasa con creces la de Passow. Cuando colacioné la parte editada del léxico de Crönert con la misma parte en Man. Crö., pude observar que en aquélla hay mucho más material recogido, ordenado y traducido que en el Man. Crö. Por 


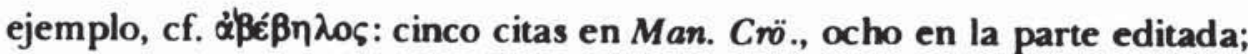
un ejemplo muy llamativo lo constituye el lema $\tilde{\alpha} \gamma$ ios. Es evidente que hubo un original enviado a la imprenta con inmenso material, ordenado por acepciones, con abreviaturas normalizadas, etc., de la parte editada

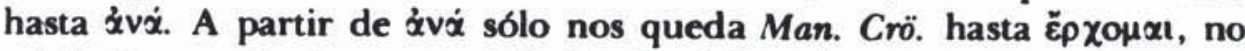
sabiéndose nada de otro original más elaborado.

Esta falta de un original más elaborado y el contar sólo con Man. Crö. fue, probablemente, el principal motivo que movió a la Academia de Ciencias de Gotinga a no seguir publicando el Diccionario hasta ع̌́ $\chi 0 \mu x l$, como había sido el último deseo de Crönert.

\section{Autores y textos que abarca Man. Crö.}

El material que se encuentra en Man. Crö. ha sido despojado de textos muy variados, con frecuencia raros y muchas veces carentes de léxicos e índices. Es evidente que Crönert leía los textos, e iba añadiendo el material lexicográfico en Man. Crö. Este es el caso de muchos autores de los contenidos en Estobeo, como Arquitas, Diotógenes, Fintis, Esara, etcétera.

Crönert hizo un gran esfuerzo para renovar las ediciones sobre las que había trabajado Passow, y por ello papeleteó ediciones raras y que había recibido recientemente. Así resulta muy interesante el material que recoge de autores técnicos y científicos (por ejemplo, Leoncio Matemático, Herón el Mecánico, Eudoxo, Papo), médicos (bastante de Hipócrates, aunque no mucho, pero sí el Anonymus Londinensis, los papiros médicos editados por Kalbfleisch, Apolonio de Citio), etc. No digamos la astronomía y la astrología: Arato y sus comentarios recogidos por Maass se encuentran ampliamente documentados.

El material procedente de Epicuro y los epicúreos forma un corpus importantísimo en Man. Crö. Epicuro, Filodemo, Demetrio Laco, Diógenes de Enoanda, etc., se hallan densamente representados en Man. Crö. Es sabido que en lo relativo a los papiros Herculanenses, Crönert prestó sus materiales a los autores del Diccionario de Liddell-Scott-Jones ${ }^{2}$. Por $\mathbf{m i}$ parte, después de haber estudiado Man. Crö., creo que casi todo el material de los epicúreos, aun el procedente de ediciones, debió proveerlo Crönert para el $L S J$.

Man. Crö. refleja también un interés grande en otros autores de la

\footnotetext{
${ }^{2}$ Como reconocen ellos mismos, s. u. Epicurus (p. XXIV) y Philodemus (p. XXXII), en la lista de autores (G. Liddell, R. Scott y H. S. Jones, A Greek-English Lexicon con Suppl., Oxford 1968).
} 
filosofia helenística. Los estoicos aparecen ampliamente documentados; Marco Aurelio está exhaustivamente despojado.

También aparece mucho material de los teóricos griegos de la retórica y la estilística (por ejemplo, Dionisio de Halicarnaso, Hermógenes, Amonio, etc.). En cuanto a poetas, aparecen recogidos casi exclusivamente los descubrimientos papirológicos de Safo y otros líricos, sus fragmentos en los lexicógrafos y, a veces, autores que, aunque breves, tienen un material lexicográfico raro e interesante, como, por ejemplo, Euforión de Calcis.

Hay un enorme material procedente de los lexicógrafos antiguos. El Focio de Reitzenstein, el Etymologicum Magnum, Genuinum, Simeonis y no digamos Hesiquio, han sido despojados por Crönert, abordándose con ello conjuntamente una de las cuestiones más arduas de la literatura griega. Con ello se añadía también al futuro diccionario un inmenso material fragmentario de los autores clásicos (líricos, trágicos, cómicos, oradores).

Crönert intentó superar en todos los campos el enfoque excesivamente clasicista de los diccionarios de griego tradicionales, enfoque del que no se libra tampoco el $L S J$. Así, Crönert incorpora material de la patrística (Gregorio Nacianceno, Hipólito, diversas Catenae, Basilio de Cesarea, Sinesio de Cirene, la Historia Lausiaca de Paladio, etc.) con intención puramente lexicográfica y de interés por la historia de la lengua, encontrándose a veces en Man. Crö. citas que no aparecen en el extenso diccionario A Patristic Greek Lexicon de Lampe, demasiado volcado al léxico puramente teológico.

También la literatura bizantina civil está reflejada en Man. Crö.: Justiniano y la Crónica de Teófanes están ampliamente documentados.

Falta, sin embargo, en Man. Crö. la recogida masiva de material lexicográfico de los autores más clásicos, aunque alguna vez aparezcan en algún esquema de la organización de una palabra larga. Apenas hay citas, por ejemplo, de los trágicos (aunque sí sus fragmentos papiráceos o contenidos en los lexicógrafos), Platón o Tucídides, cuyo léxico está admirablemente recogido, ordenado y traducido en la parte editada de $\alpha$ a $\alpha v \alpha \dot{\alpha}$.

\section{Material procedente de los papiros}

Crönert era un experto papirólogo. Conocida es su actividad de interpretación de los papiros Herculanenses, sus ediciones (el Kolotes und Menedemos, la Vita Philonidis, sus estudios paleográficos, gramaticales y lexicológicos pioneros sobre la lengua de los papiros en su Memoria 
Graeca Herculanensis de 1903). La cuestión de la incorporación del léxico papirológico literario y no literario a los diccionarios generales, le preocupaba en gran manera. Lo que él llama la papyri Frage es estudiada por él como cuestión lexicográfica en unas hojas sueltas manuscritas que se encuentran en el vol. I de Man. Crö. Como ya hemos dicho antes (cf. supra), sabido es que fue él quien aprovisionó del material papirológico Herculanense a los autores del LSJ. Pero el material que aparece en Man. Crö. procedente de papiros literarios y no literarios es ingente, y creo que tiene un interés extraordinario a pesar de la existencia de léxicos especiales de papiros (no literarios). Su despojo de los papiros literarios o de los tratados científicos $y$, sobre todo, de los papiros mágicos es único y representa un esfuerzo considerable. No digamos el material procedente de Milne, A Greek Shorthand Manual, y de otros manuales de taquigrafia antigua, cuyo interés lexicográfico nos descubre Crönert, pues en realidad se trata de un tipo especial de glosario. Crönert tenía un gran interés por la taquigrafia antigua: los libros que hay en su biblioteca sobre este tema están plagados de notas y convertidos en auténticos ejercicios paleográficos de su propia mano.

\section{Material procedente de las inscripciones}

Creo que el material procedente de inscripciones es casi lo más importante de la aportación de Man. Crö. En él se encuentran despojadas muchas colecciones, dialectales, como las que se encuentran en $I G$, en el $B C H, S E G$, las inscripciones de Priene, Magnesia, Olimpia, etc. Con ser esto útil, pues no existen léxicos ni índices generales de las inscripciones, estimo que es más importante su aportación de material aparentemente banal de inscripciones que son ya de la kotví, como las contenidas, por ejemplo, en los últimos volúmenes de IG. Revelan cómo el léxico literario y semiliterario griego se ha incorporado masivamente a la epigrafía en géneros no necesariamente literarios. En este sentido, como en otros, Crönert se nos revela como el destructor de $\ddot{\alpha} \pi \alpha \xi$, como el documentador de usos institucionales que sólo se conocían por autores literarios.

\section{LEXICOLOGÍA}

Crönert reunió miles de separatas, muchas de ellas rarísimas, felizmente guardadas en el Seminar für Klassische Philologie de Gotinga, sobre temas concretos de palabras griegas, su sintaxis y morfología. 
Aparecen con frecuencia en Man. Crö. en referencias adscritas a los lemas o en hojas sueltas dentro de los volúmenes manuscritos. Hice una breve revisión de varias de ellas, tomando algunas notas, pero ello exigiría un estudio complementario y muy detenido que me era imposible realizar en aquellos meses. Dejo esto como información para tesis doctorales que se están realizando en nuestro ámbito.

\section{FORMALIZACIÓN DE LAS REFERENCIAS}

La forma de citar es, en general, en Man. Crö. la parte menos elaborada o con criterios menos definidos y discutibles, frecuentemente divergentes de la parte editada. Separa los números de las citas no por puntos o comas, sino por tamaños. Para las inscripciones tiende a utilizar minúsculas: ig (=IG en $L S J, D G E)$, di $(=G D I)$, pero no es infrecuente que aparezca DI. Tras las inscripciones pone el lugar y año, aunque de forma no normalizada. En todos los casos una $i$ inicial volada indica inscripción, bien de publicación especializada ('Prien., iMilet., 'Did., 'Magn., etc.) o en publicaciones que se ocupan de otras cosas ('Arch. indica inscripción de la revista Archiv für Papyrusforschung).

En los papiros hay mayor uniformidad, tal vez porque desde el nacimiento de la papirología ha habido ya una tendencia hacia la formalización, aunque el caos internacional en la denominación de papiros es importante.

Tampoco la forma de citar los autores está unificada, y ello revela et carácter provisional del material a la espera de una elaboración ulterior por parte de su autor. Se cita, por ejemplo, «Diotog. bei Stob. Fl. 3. 1. 100» y en la página de al lado «Diotog. bei Stob. 3. 1. 100x. Marco Aurelio aparece como Mar. A., siempre subrayado, y la numeración puede ser, por ejemplo, II 3 normalmente, pero no se descarta la aparición como $2_{3}$ o como 2 III. Todo esto produce gran confusión en la lectura del manuscrito, dificultad que pude suplir gracias a nuestra experiencia de manejo de un gran corpus de referencias de la literatura griega al trabajar durante tanto tiempo en el $D G E$.

A pesar de la dificultad de lectura (al principio podía leer sólo ocho páginas diarias) conseguí identificar casi todas las citas de Man. Crö., reuniendo casi 200 páginas de notas que luego debieron ser colacionadas y reelaboradas de acuerdo con el material y los criterios que seguimos en el Diccionario Griego-Español. Esta reelaboración me llevó otros dos meses. 
V. UTILIZACIÓN DE MAN. CRÖ. PARA la leXICOGRAFía GriEGa

A la luz de las consideraciones anteriores puede deducirse que la lectura y estudio de Man. Crö. resulta de un interés excepcional para el Diccionario Griego-Español y para cualquier otro diccionario griego de cierta envergadura. A pesar de la dificultad evidente de su lectura (el griego y las citas están en letra pequeña, aunque extremadamente clara, pero las traducciones vienen en escritura gótica manual, que ya es difícil de leer incluso para las generaciones alemanas más jóvenes), Man. Crö. resulta útil precisamente para personas como las que llevamos muchos años trabajando en un gran léxico que tiene ya una gran masa de material recogido, y no para consultas individuales. Tal vez sea éste el motivo por el que Man. Crö. no haya sido casi estudiado en más de treinta años.

Elvira Gangutia Elícegui 